\title{
Advances in understanding immunity to Toxoplasma gondii
}

\author{
Elia D Tait, Christopher A Hunter/ ${ }^{+}$ \\ Department of Pathobiology, School of Veterinary Medicine, University of Pennsylvania, Hill Pavilion, Rm 341, 380 \\ South University Avenue, Philadelphia, PA, USA 19104
}

Toxoplasma gondii is an important cause of clinical disease in fetuses, infants and immunocompromised patients. Since the discovery of $\mathrm{T}$. gondii 100 years ago, this pathogen and the host's immune response to toxoplasmosis have been studied intensely. This has led to the development of a working model of immunity to T. gondii, and has also resulted in fundamental new insights into the role of various cytokines in resistance to infection. By examining this organism, researchers have identified many of the requirements for resistance to intracellular pathogens and characterized numerous regulatory factors, including interleukin-10 (IL-10) and IL-27, which control inflammatory processes. In the next 100 years of T. gondii immunobiology, researchers will have the opportunity to answer some of the long-standing questions in the field using new techniques and reagents. These future studies will be vital in building a more comprehensive model of immunity to this pathogen and in advancing our understanding of immunoregulation, particularly in humans. Ultimately, the challenge will be to use this information to develop new vaccines and therapies to manage disease in affected patients.

Key words: Toxoplasma gondii immunology - cytokines - microscopy - protozoan vaccines

In 1907, at the Institut Pasteur in Tunis, while studying the infectious diseases of the desert rodent, Ctenodactylus gundii, Charles Nicolle observed the presence of a crescent-shaped organism in the tissues of these animals (Nicolle 1907). In 1908, Nicolle and his collaborator, Louis Manceaux, published the initial description of this discovery (Nicolle \& Manceaux 1908). A year later, they provided a more complete report and named the organism Toxoplasma gondii, referencing the parasite's characteristic morphology and the source of the original isolate (Nicolle \& Manceaux 1909). Concurrently, in Brazil, Alfonso Splendore (1908) identified the same microbe as a parasite of rabbits (Splendore 1908). At the time, the discovery of $T$. gondii perhaps seemed to be solely of academic interest; however, when Wolf et al. (1939) discovered the parasite in infants with encephalomyelitis, $T$. gondii was recognized as a cause of congenital disease.

Since $T$. gondii's discovery, its clinical importance has influenced the research groups investigating the immunobiology of toxoplasmosis. Today, T. gondii is recognized as an important opportunistic pathogen of fetuses, newborns and patients with a variety of primary genetic and acquired immunodeficiencies (Petersen \& Dubey 2001). The majority of immunocompromised patients that develop clinical disease have defects in $\mathrm{T}$ cell function, highlighting the importance of lymphocytes in controlling this persistent infection. Consequently, there has been a focus on understanding how $\mathrm{T}$ cells provide protection against disease and how cytokines modulate

Financial support: T32 AI007532, RO1 AI041158

+Corresponding author: chunter@vet.upenn.edu

Received 10 October 2008

Accepted 31 October 2008
T cell responses (Lieberman \& Hunter 2002). This review will provide an overview of these events, consider how the study of $T$. gondii has had a significant impact on the field of immunology and discuss future studies that may provide new insights into the mechanisms necessary for the control of this pathogen.

\section{The first 100 years: T. gondii immunobiology}

T. gondii is one of the world's most prevalent and successful parasites. Its biology is complex and numerous researchers worked throughout the 1960s and 1970s to elucidate the life cycle and means of transmission (Ajioka \& Soldati 2007). This body of work is summarized elsewhere in this issue and here we focus on the immune responses that lead to the control of the asexual tachyzoite and bradyzoite forms.

Intermediate hosts become infected with $T$. gondii after ingesting oocysts in the environment or tissue cysts from infected animals. Parasite replication in the intestine eventually leads to host cell lysis and parasite egress and tachyzoites disseminate throughout the host (Petersen \& Dubey 2001). This process is poorly understood, but recent work suggests that $\mathrm{CD} 11 \mathrm{c}^{+}$dendritic cells (DC) may act as Trojan horses to spread the infection (Courret et al. 2006, Lambert et al. 2006). In immunodeficient hosts or during primary infection with highly virulent strains, the immune system cannot control parasite replication and clinical disease results (Fuentes et al. 2001). In most healthy hosts, the immune response controls replication, disease is limited, and physiological stress on the parasite causes tachyzoites, primarily in the brain and muscle tissue, to differentiate into bradyzoite cysts that persist throughout the host's life. Tissue cysts undergo periodic reactivation, but these events are controlled by an intact immune system. However, in chronically infected hosts that lose $\mathrm{T}$ cell function, reactivation may lead to disease (Petersen \& Dubey 2001). 
The study of $T$. gondii immunobiology began in the 1940s, with Sabin and Feldman's (1948) description of complement-fixing antibodies to T. gondii in immune serum that led to the development of the Sabin-Feldman dye-test for sero-diagnosis. Subsequently, during the late 1960s, two vital components of the host immune response to $T$. gondii were uncovered. In 1968, Brownlee, Remington and others provided the first reports that $T$. gondii infection led to interferon production (Freshman et al. 1966, Remington \& Merigan 1968, Rytel \& Jones 1968). In 1967, Frenkel described the role of cell-mediated immunity in protection against this pathogen in the Golden hamster (Frenkel 1967) and, in 1972, Remington et al. established the importance of macrophages in controlling replication of $T$. gondii. These studies laid the groundwork for the next 40 years of work in the field, in which researchers focused on the cytokine and cell-mediated components of immunity required for resistance to this organism.

During the 1970s and 1980s, the population of immunocompromised hosts grew dramatically and the incidence of opportunistic infections increased. Transplant and cancer patients on newly-developed immunosuppressive drugs, and patients with immunosuppressive cancers, had an increased incidence of toxoplasmosis caused by parasite reactivation in the latently infected host (Remington 1974). In the early 1980s, with the emergence of the human immunodeficiency virus (HIV) and acquired immune deficiency syndrome (AIDS), a new cohort of immunosuppressed patients deficient in $\mathrm{CD}^{+}$ $\mathrm{T}$ cells was identified. These patients were susceptible to a variety of intracellular pathogens, including $T$. gondii, and presented with symptoms of toxoplasmic encephalitis (TE) following parasite reactivation (Horowitz et al. 1983, Pitchenik et al. 1983, Luft et al. 1984, Levy et al. 1988, Jones et al. 1996). These clinical observations were corroborated experimentally in studies in the mouse model, in which depletion of $\mathrm{CD}^{+}$or $\mathrm{CD} 8^{+} \mathrm{T}$ cells during chronic infection resulted in TE (Vollmer et al. 1987, Suzuki \& Remington 1988, Gazzinelli et al. 1991, 1992b, Parker et al. 1991). Together, these clinical observations and laboratory studies provided evidence for the vital role for $\mathrm{CD}^{+}$and $\mathrm{CD} 8^{+} \mathrm{T}$ cells in the longterm control of $T$. gondii.

Following the initial reports in the late 1960s that described interferon production in response to $T$. gondii, cellular immunity and cytokine production were linked in 1983 when Rubin et al. reported that interferon- $\gamma$ (IFN- $\gamma$ ) produced by $\mathrm{T}$ lymphocytes activated macrophages to produce reactive oxygen intermediates (ROI) and kill T. gondii (Nathan et al. 1983). By the late 1980 s, IFN- $\gamma$ produced by $\mathrm{CD}^{+}$and $\mathrm{CD} 8^{+} \mathrm{T}$ cells was identified as the major mediator of protection against T. gondii (Suzuki et al. 1988, 1989) and there were suggestions that accessory cell products were responsible for inducing IFN- $\gamma$ production from $\mathrm{T}$ lymphocytes and natural killer (NK) cells (Kelly et al. 1989). At the same time, Trinchieri and colleagues had identified the heterodimeric cytokine interleukin-12 (IL-12) as a "powerful immunopotentiating agent" (Kobayashi et al. 1989, Chan et al. 1991) that stimulated IFN- $\gamma$ production from human and murine $\mathrm{T}$ lymphocytes and NK cells. The
Sher, Kasper and Remington laboratories established that IFN- $\gamma$ production in response to $T$. gondii was largely IL-12-dependent in both immunodeficient and immunocompetent mice, with important roles for IL-2 and tumor necrosis factor- $\alpha$ (TNF- $\alpha$ ) as co-factors (Gazzinelli et al. 1993, 1994a, b, Hunter et al. 1994, 1995, Khan et al. 1994). Macrophages (Gazzinelli et al. 1993), DC (Reis e Sousa et al. 1997, Liu et al. 2006) and neutrophils (Bliss et al. 1999) were all identified as sources of IL-12 during toxoplasmosis, although DC, including conventional $\mathrm{CD}^{+}$(Reis e Sousa et al. 1997) and plasmacytoid DC (Pepper et al. 2008), now appear to be the major contributors (Liu et al. 2006). These different cell types become activated and produce IL-12 following the engagement of either chemokine (C-C motif) receptor 5 (CCR5) (Aliberti et al. 2000) or Toll-like receptors (TLR), including TLR 2 (Mun et al. 2003) and TLR 11 (Yarovinsky et al. 2005) by parasite-derived molecules.

In recent years, the study of IFN- $\gamma$-dependent effector mechanisms that limit parasite replication have underlined the importance of the IL-12/IFN- $\gamma$ axis. IFN- $\gamma$ signals through signal transducer and activator of transcription 1 (STAT1) to activate a variety of antimicrobial effector mechanisms, including the upregulation of inducible nitric oxide synthase (iNOS). ROI produced by iNOS were initially thought to be the host's primary means of controlling parasite replication, as illustrated by the increased susceptibility of iNOS knockout mice. However, unlike IFN- $\gamma$ knockout mice, iNOS knockout mice survive the acute phase of infection and do not succumb until the chronic phase. These data indicated the presence of IFN- $\gamma$-dependent, iNOS-independent pathways to inhibit parasite growth (Scharton-Kersten et al. 1997). One such pathway includes the activation of the family of p47 guanosine triphosphatases (GTPases), which are upregulated in response to IFN- $\gamma$ (Taylor et al. 2000, Collazo et al. 2001). Studies utilizing specific p47 GTPase knockout animals have provided evidence that these proteins degrade the parasitophorous vacuole in $T$. gondii-infected cells and are involved in the process of autophagy (Martens et al. 2005). Ultimately, though mice deficient in STAT1 (Gavrilescu et al. 2004, Lieberman et al. 2004), iNOS (Scharton-Kersten et al. 1997) and members of the $47 \mathrm{kD}$ GTPase family (Taylor et al. 2000, Collazo et al. 2001) all show increased susceptibility to $T$. gondii infection, we still do not fully understand the mechanisms by which IFN- $\gamma$ mediates protection. Ongoing studies seek to better characterize IFN- $\gamma$ dependent anti-parasitic effector mechanisms.

Taken together, the studies reviewed here, and others, have led to the development of a model of immunity to T. gondii, summarized in the Figure. Accessory cells, notably DC, recognize that the host is infected with $T$. gondii, likely through pattern recognition receptors. These cells become activated and produce IL-12, which promotes NK cell production of IFN- $\gamma$. IL-12 derived from antigen presenting cells (APC), in the context of antigen presentation, also drives $\mathrm{CD} 4^{+}$and $\mathrm{CD} 8^{+} \mathrm{T}$ cell activation and IFN- $\gamma$ production. In addition, activated $\mathrm{CD}^{+} \mathrm{T}$ cells produce IL-2, an important $\mathrm{T}$ cell mitogen. Together, these events result in the convergence of large 


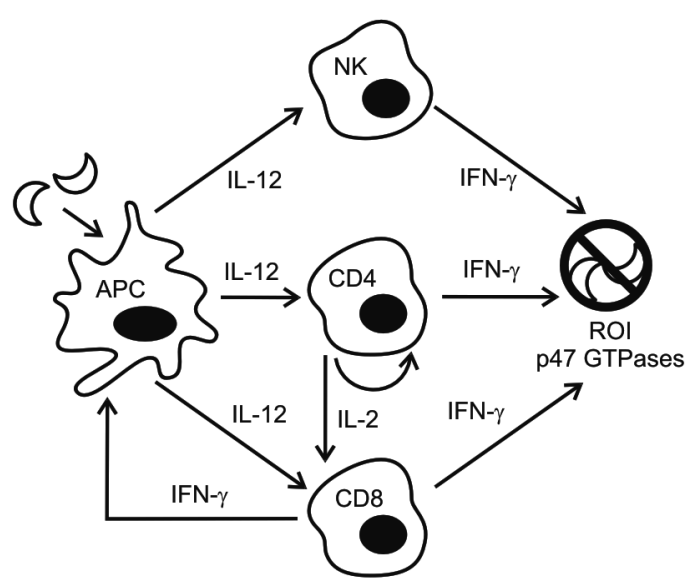

Immunity to Toxoplasma. Antigen presenting cells (APC) recognize T. gondii infection and become activated. IL-12 produced by activated APC (or neutrophils) induces production of IFN $-\gamma$ from natural killer (NK) cells. In conjunction with antigen presentation, IL-12 also activates $\mathrm{CD} 4^{+} \mathrm{T}$ cells to produce IL-2, a T cell mitogen, and $\mathrm{CD} 4^{+}$and $\mathrm{CD} 8^{+} \mathrm{T}$ cells to produce IFN $-\gamma$. IFN- $\gamma$ signaling promotes the development of a number of activator of transcription 1 (STAT1)-dependent anti-parasitic effector mechanisms, including reactive oxygen intermediates (ROI) production and p47 GTPase upregulation. The cell mediated immune response that results limits parasite replication.

numbers of parasite-specific $\mathrm{CD}^{+}$and $\mathrm{CD}^{+} \mathrm{T}$ cells that produce IFN- $\gamma$ at sites of parasite invasion. IFN- $\gamma$ signaling, in a STAT1-dependent pathway, leads to the generation of anti-parasitic effector mechanisms, including the production of ROI and the activation of the p47 GTPases.

\section{Immunoregulation during $T$. gondii infection}

The study of the immune response to parasites has consistently provided new insights into the importance of cell-mediated immunity and the role of cytokines in the control of intracellular pathogens. For example, the study of the interactions between $T$. gondii and the host has provided a better understanding of how an immune response is initiated, expanded, and contracted to limit pathogen growth and replication while controlling immunopathology. Many mechanisms have been identified that modulate infection-induced pathology, including the activity of lipoxins, IL-10 and IL-27 (Lieberman \& Hunter 2002, Aliberti 2005). Two of the most important anti-inflammatory cytokines, IL-10 and IL-27, have been studied extensively during toxoplasmosis and this work has contributed to the basic understanding of the function of these factors.

IL-10 limits infection-induced immune pathology - In 1989, a new cytokine, initially called cytokine synthesis inhibitory factor, and later designated as IL-10, was identified based on its ability to antagonize T helper 1 (Th1) responses (Fiorentino et al. 1989). Today, IL-10 is considered to be an inhibitor of Th1, Th2 and Th17 immune responses (Moore et al. 2001, Lieberman \& Hunter 2002, O'Garra \& Vieira 2007). It is produced by macrophages, monocytes, DC, B cells, and $\mathrm{CD}^{+}$and $\mathrm{CD} 8^{+} \mathrm{T}$ cells, and acts broadly on accessory cells to downregulate proinflammatory cytokine production and major histocom- patibility complex (MHC) and costimulatory molecule expression. Thus, $\mathrm{T}$ cell priming and activation are dampened primarily through IL-10's effects on accessory cells, although there are reports that IL-10 may also directly suppress $\mathrm{CD}^{+} \mathrm{T}$ cell proliferation and cytokine production (Couper et al. 2008).

In 1992, the Sher laboratory reported, consistent with IL-10's inhibitory effects on macrophages, that IL-10 antagonized the ability of IFN- $\gamma$-primed macrophages to kill intracellular T. gondii (Gazzinelli et al. 1992a). Also at this time, IL-10 was identified as a factor induced by $T$. gondii infection (Gazzinelli et al. 1992a, 1994a, Hunter et al. 1993, Burke et al. 1994) that contributed to the suppression of T cell function (Candolfi et al. 1995, Khan et al. 1995). These findings contributed to a model in which T. gondii induces IL-10 production to limit the host immune response and favor parasite replication. Unexpectedly, IL-10 ${ }^{-/-}$mice infected with $T$. gondii succumbed to systemic inflammatory disease (Gazzinelli et al. 1996, Neyer et al. 1997) mediated by CD4 ${ }^{+} \mathrm{T}$ cells (Gazzinelli et al. 1996, Suzuki et al. 2000, Wilson et al. 2005) and dependent on CD40-CD40L and CD28-CD80/CD86 interactions (Villegas et al. 2000, Wille et al. 2002). Thus, IL-10 was established as a vital player in the control of immunopathology during toxoplasmosis.

Given the importance of IL-10 in preventing and limiting inflammation, identifying the source of this cytokine has become an important issue. In 2007, Sher et al. identified $\mathrm{CD}^{+} \mathrm{Tbet}^{+}$Foxp3- Th1 cells that produced large amounts of IFN- $\gamma$ and were also potent sources of protective IL-10 (Jankovic et al. 2007). These cells do not appear to be regulatory $\mathrm{T}$ cells, but rather effectors that also possess the capacity to produce IL-10 and limit immune pathology. This study, and others that found similar results in different systems, indicates that autoregulatory mechanisms that promote effector $\mathrm{CD}^{+} \mathrm{T}$ cell production of IL-10 have a key role in maintaining balanced, yet efficacious, immune responses to T. gondii and other pathogens (O'Garra \& Vieira 2007).

Though the importance of IL-10 in T. gondii infection is clear, questions remain regarding how IL-10 integrates with other immunoregulatory pathways. Though $\mathrm{CD}^{+} \mathrm{T}$ cells are an important source of IL-10 during toxoplasmosis, there are other cellular sources of IL-10 during acute and chronic infection and their relative contribution to the control of immune-mediated pathology is unclear. Additionally, how these cytokine-producing cells migrate and behave in secondary lymphoid organs versus sites of tissue inflammation is unknown. In order to address these questions, new approaches and reagents are being developed, including intravital imaging and IL-10 reporter mice and these advances will provide opportunities to better understand this regulatory cytokine.

IL-27: a new anti-inflammatory cytokine - In 2002, researchers at DNAX described a heterodimeric cytokine, IL-27, composed of the p28 and Epstein Barr virus-induced gene 3 (EBI3) subunits. The p28 subunit was identified in a computational screen designed to identify homologs of the IL-6/IL-12 family of cytokines, and EBI3 was identified as a 28 binding partner in immunoprecipitation and 
secretion studies (Pflanz et al. 2002). Initial findings indicated that IL-27 was produced by APC, and acted on naïve $\mathrm{T}$ cells to induce proliferation and Th1 polarization (Pflanz et al. 2002). These effects were mediated by IL-27 binding its receptor, composed of IL-27 receptor $\alpha$ (WSX-1) and glycoprotein 130, and signaling through STAT1 to induce expression of T-bet and IL-12 receptor $\beta 2$ (Hibbert et al. 2003, Lucas et al. 2003, Takeda et al. 2003, Villarino et al. 2003, Pflanz et al. 2004).

Although the initial characterization suggested that IL-27 had proinflammatory properties, when WSX-1 deficient mice were challenged with $T$. gondii, they succumbed to infection and had unexpectedly low parasite burdens and significant immunopathology. These mice had high levels of Th1 cytokines, increased T cell activation and proliferation, and cellular infiltrates and tissue destruction in the liver and lungs. The immune pathology noted was dependent upon the presence of $\mathrm{CD}^{+}$ $\mathrm{T}$ cells, demonstrating a phenotype similar to that observed in IL-10 deficient animals; however, overall IL10 levels were not decreased in acutely infected WSX-1 deficient animals. In vitro studies indicated that IL-27 was only proinflammatory in conditions in which IL12 was limiting, whereas in conditions where IL-12 was abundant (as in toxoplasmosis), IL-27 actually played a suppressive role (Villarino et al. 2003). Subsequent studies in other models of infectious and autoimmune disease have confirmed an anti-inflammatory role for IL27 in Th1 (Rosas et al. 2006, Wirtz et al. 2006, Sonoda et al. 2007), Th2 (Artis et al. 2004, Miyazaki et al. 2005, Shimizu et al. 2005) and Th17 responses (Batten et al. 2006, Stumhofer et al. 2006, Fitzgerald et al. 2007), and it can directly induce IL-10 production (Awasthi et al. 2007, Fitzgerald et al. 2007, Stumhofer et al. 2007).

The study of IL-27's role during toxoplasmosis has yielded important insights into its biological activities, as well as emphasizing the importance of immunoregulation during infection. However, the function and regulation of IL-27 during $T$. gondii infection is still poorly understood. The cellular sources of IL-27, it's role during chronic versus acute infection, the contributions of the p28 and EBI3 subunits, and how it intersects with other cytokine signaling networks, including the importance of the EBI3 subunit in IL-35 signaling (Collison et al. 2007), are open questions. As has been the case for IL-10, the study of IL-27 during toxoplasmosis promises to further our understanding of $T$. gondii immunobiology and the function of IL-27.

\section{The next 100 years: new challenges in T. gondii im- munobiology}

In the 100 years since the discovery of $T$. gondii, we have developed a complex picture of the events vital for controlling toxoplasmosis. This area of study has consistently been at the forefront of immunology and researchers are taking advantage of new culture techniques, immunological assays and animal models, including knockout and transgenic mice, to better understand how the host is able to recognize and control this pathogen. While there has been enormous progress in this field, many questions remain. Particularly, the capacity of cy- tokines to regulate $\mathrm{T}$ cell responses in vivo is not fully understood and the events that occur during the human immune response to toxoplasmosis are unclear. The following section will provide a personal perspective on some of the questions and areas of investigation that will help address these specific questions.

Imaging the immune response to T. gondii - Historically, in order to examine immune responses at the cellular level, immunologists have relied upon techniques and reagents that provided "snapshots" of lymphocyte behavior at a given time point, long after early activation or priming events had occurred (Mempel et al. 2004, Sumen et al. 2004, Germain et al. 2005, 2006, Garside $\&$ Brewer 2008). Some of the outstanding questions in the field of $T$. gondii immunology involve understanding how cytokine-producing accessory cells and $\mathrm{T}$ cells interact to coordinate a protective immune response and, subsequently, how effector T cells interact with $T$. gondiiinfected cells to control parasite replication. Addressing these issues will require a more dynamic approach to analyzing cellular immunity, in which cell-cell interactions in vivo can be observed in real-time. In the past decade, advances in whole-body animal imaging and intravital multiphoton (MP) microscopy have provided new tools to observe and study the behavior of single cells. Here we will provide examples of questions in the field that have been addressed using imaging technology and discuss how these studies can be extended to further investigate the behavior of individual immune cells during toxoplasmosis.

Until recently, we have had a limited insight into how T. gondii-infected cells behave in vivo during toxoplasmosis and how T cells and APC interact with infected cells. The development of transgenic parasite lines that express fluorescent (Striepen et al. 1998) or bioluminescent proteins has allowed for imaging and flow cytometry studies that analyze infected cells in vivo and in vitro. Using parasites that express luciferase in conjunction with whole-body animal imaging techniques, patterns of T. gondii dissemination (Hitziger et al. 2005, Saeij et al. 2005), reactivation (Dellacasa-Lindberg et al. 2007) and stage conversion (Saeij et al. 2008) in vivo have been described. Fluorescent parasites have been used to char-

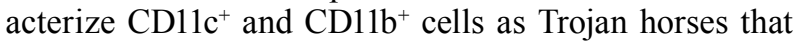
spread T. gondii throughout the host (Courret et al. 2006, Lambert et al. 2006), investigate apoptotic and cytolytic pathways in infected cells (Persson et al. 2007), describe how infected cells present $T$. gondii antigen (Gubbels et al. 2005, Dzierzsinski et al. 2007) and examine interactions between parasites and DC (Boes et al. 2002, McKee et al. 2004). Additionally, transgenic parasite lines that express a model antigen, such as ovalbumin (Pepper et al. 2004 , Gubbels et al. 2005), $\beta$-galactosidase (Kwok et al. 2003) or E $\alpha$ (Pepper et al. 2008), allow antigen-specific $\mathrm{T}$ cell responses to be tracked. Using bioluminescent and fluorescent parasites in conjunction with model antigen systems, the interaction between infected target cells and antigen-specific $\mathrm{T}$ cells can be investigated using existing technologies (Dzierszinski \& Hunter 2008) and, ultimately, as resolution improves, it may be possible to visualize these interactions using whole-body imaging. 
While multiple groups have identified important roles for inflammatory and immunoregulatory cytokines during toxoplasmosis, additional studies will be required to identify the cellular sources of these factors and determine when and where they are produced. To date, the tools to investigate these issues have had limitations. Ex vivo cytokine production has been assayed in response to a stimulus, using intracellular cytokine staining or enzyme-linked immunoassay as read-outs, but stimulating cells in this manner may not reflect the events that occur in vivo (Mohrs et al. 2001). An alternative approach to studying these cells is through the use of cytokine-reporter mice, in which an appropriate cytokine promoter drives the expression of a fluorescent protein. Today, there are reporters available for multiple cytokines, including IFN- $\gamma$ (Stetson et al. 2003), IL-4 (Mohrs et al. 2001), IL-10 and IL-12p40 (Reinhardt et al. 2006). Thus far, these reporters have been used primarily in flow-based assays to detect cytokine-producing cells. However, these animals lend themselves well to imaging studies, including MP microscopy, and could be applied to investigate real-time immune responses to T. gondii. In the past decade, advances in the field of MP microscopy have allowed researchers to image deep into tissues for long periods of time to accurately monitor and quantitate lymphocyte behavior and migration in vivo. MP microscopy uses pulses of low-energy, high-density photons to excite fluorophors, allowing for four-dimensional analysis of immune cells with minimal photobleaching. Intravital MP microscopy, in conjunction with the development of new fluorescent reagents and surgical techniques, has led to the development of novel questions and hypotheses (reviewed in Mempel et al. 2004, Sumen et al. 2004, Germain et al. 2005, 2006, Garside \& Brewer 2008). Cytokine reporter mice will provide new insights into how cytokine-producing cells migrate and interact with other cells. This work will be important in understanding the broad orchestration of cytokine production throughout an immune response and the detailed role of the cytokine-producer in distinct microenvironments.

In addition to examining the migration and behavior of cytokine-producing cells, other issues in T. gondii immunology can be addressed using MP microscopy. These include determining what interactions T cells and APC participate in, and how T cells, APC and other cell types migrate and behave during primary infection (Chtanova et al. 2008). Imaging studies using reporter mice for lineage-specific cell surface markers can be used to quantitate the location, frequency and duration of encounters between T cells and various APC. This information will give us a better understanding of how effector $T$ cells are primed and activated and whether migration within lymphoid tissues and through sites of infection differs. Notably, the nature of lymphocyte behavior, migration and cell-cell interactions in the brains of chronically infected mice is largely unknown. Intravital MP imaging will be key in developing a model of the cellular immune response in this tissue site.

Human immunology - While toxoplasmosis has been recognized as an important human disease for almost 75 years, the rodent has been the model of choice to study the immune response to $T$. gondii. Rodents are natural hosts of this organism, are easy to use and maintain, can be genetically manipulated to produce knockouts and transgenics and there is a wide array of reagents to study the murine immune system. Additionally, the technical and ethical difficulties of human research have presented a substantial challenge to researchers with an interest in better understanding how the human host interacts with the parasite. Thus, with notable exceptions, we know little about the human immune response to toxoplasmosis. While most immunocompetent humans that become infected with $T$. gondii are asymptomatic, the parasite can cause disease in two main groups of people: those with acquired or primary immunodeficiencies and fetuses infected in utero (Petersen \& Dubey 2001). These two classes of patients present different challenges to health professionals in terms of diagnosis, case management and drug treatment. For basic researchers, studying how and why disease occurs in susceptible patients may provide the opportunity to develop new vaccines and immune-based therapies.

Congenital toxoplasmosis occurs in infants that are infected during gestation, following a primary challenge of the mother (Wong \& Remington 1994). Interestingly, not all pregnant women that contract a primary infection transmit the parasite to their fetus. The mechanisms that influence vertical transmission are poorly defined, although there is a positive correlation between rate of transmission and infection during the second or third trimester of pregnancy (Desmonts \& Couvreur 1984, Dunn et al. 1999). The placenta itself also appears to play an important role in mediating transmission (Pfaff et al. 2007) and studies in the murine model suggest a role for IFN- $\gamma$ in facilitating transmission (Abou-Bacar et al. 2004). Additionally, there is evidence that fetuses infected in utero may be tolerized to $T$. gondii antigens in both the mouse (Suzuki \& Kobayashi 1990) and the human (McLeod et al. 1985, Hara et al. 1996, Yamamoto et al. 2000). However, the nature of the fetal response to T. gondiii challenge, and how this response ultimately impacts the long-term consequences of in utero infection, is unclear.

One of the most important challenges in managing congenital toxoplasmosis is developing effective preventative measures. In mothers previously exposed to $T$. gondii, the fetus is very rarely infected (Remington et al. 2000), suggesting that natural maternal immunity to T. gondii is sufficient to protect the fetus from vertical transmission. In principle, this protection could be mimicked using a vaccine. Numerous strategies have been employed to elicit protective immunity in mouse models of congenital toxoplasmosis, including recombinant protein (Letscher-Bru et al. 2003) and DNA-based vaccine strategies (Mévélec et al. 2005), but to date, a human vaccine has not been developed.

In the immunocompetent murine host during secondary challenge, $\mathrm{CD} 8^{+} \mathrm{T}$ cells are vital in mediating protection (Gazzinelli et al. 1991). This observation suggests that a successful vaccine should mobilize parasite-specific $\mathrm{CD} 8^{+} \mathrm{T}$ cells to prevent primary infection (Pfaff et al. 2007). Unfortunately, the study of antigenspecific $\mathrm{T}$ cell responses in humans has been limited 
due to reagent availability and thus the evaluation of human cellular responses to vaccines has been difficult. In the past decade however, numerous groups have developed MHC class I tetramer reagents to identify and study antigen-specific $\mathrm{CD} 8^{+}$(Serbina \& Pamer 2003) and $\mathrm{CD}^{+}$(Mallone \& Nepom 2004) $\mathrm{T}$ cells in human viral and bacterial infections. These reagents specifically identify $\mathrm{T}$ cells with the $\mathrm{T}$ cell receptor (TCR) for a peptide of interest and have been used to track vaccinespecific responses in humans (Serbina \& Pamer 2003). Recently, a number of groups have collaborated to develop tetramer reagents for immundominant $T$. gondii $\mathrm{CD} 8^{+} \mathrm{T}$ cell epitopes in the murine model (Blanchard et al. 2008, Frickel et al. 2008). This approach could be applied to develop tetramers for use in human studies, so that the $T$. gondii-specific $\mathrm{T}$ cell responses of newborns infected in utero and vaccinated women before and during pregnancy could be examined. The development of these tetramer reagents would allow for the detailed investigation of fetal anergy in response to $T$. gondii antigens and would provide a read-out of vaccine efficacy.

Patients with primary or acquired immunodeficiencies represent a broad group of individuals with various deficits in T cell, monocyte, cytokine and B cell function. Cancer patients with immunosuppressive cancers, including leukemia and lymphoma, experience recrudescence of chronic infection as $\mathrm{T}$ cell function declines. Cancer or transplant patients receiving immunosuppressive drugs as part of a chemotherapeutic regimen also present with reactivated toxoplasmosis (Armstrong et al. 1971, Ruskin \& Remington 1976, Frenkel et al. 1978, Hakes \& Armstrong 1983, Derouin et al. 1992, Israelski \& Remington 1993, Lappaleinen et al. 1998). Patients with hyper-IgM syndrome, in which the CD40/CD40L interaction is disrupted, resulting in defects in cell-mediated immunity and an inability to class switch (Aversa et al. 1994), are susceptible to primary infection (Subauste et al. 1999). Finally, HIV-infected patients, as described above, have an increased incidence of TE (Horowitz et al. 1983, Pitchenik et al. 1983, Luft et al. 1984, Levy et al. 1988, Jones et al. 1996). Widespread use of highly active anti-retroviral therapy (HAART) has led to better control of viral replication, accompanied by an increase in immune function; thus, TE and other opportunistic infections are not as prevalent in these patients as was once the case. However, new immunosuppressed cohorts are continually emerging, including patients with autoimmune disorders being treated with immunmodulatory drugs (Hemmer et al. 2006), and growing drug resistance to HAART may result in the reemergence of TE as a clinical problem in HIV/AIDS patients (Alfonso et al. 2002, Wensing \& Boucher 2003). Together, these at-risk patient groups present challenges for basic human immunology research and clinical management.

Patients with increased susceptibility to toxoplasmosis provide the researcher with the opportunity to better understand how the human immune system functions. Importantly, these patient cohorts highlight the need for innovative new drug treatments and effective therapies (Fischer 2007). With new advances in human immunology, including the application of multi-color flow cy- tometry for detection of cell surface markers, cytokine expression and intracellular cell signaling molecules, researchers and clinicians will be able to develop a better understanding of human immunity to $T$. gondiii and will also have a greater ability to assess the efficacy of treatment. These tools also promise to be useful in identifying and developing immunomodulators and immune therapies to manage this infection. Since the intact human immune response controls parasite replication effectively in most cases, immune therapy to replace or augment dysfunctional immune responses in patients with immunodeficiencies may be an effective approach to managing this condition (McCabe 2001).

In the first 100 years of research in T. gondii immunology, we have developed an initial model to understand the complexity of the immunoregulatory networks that limit immunopathology and control infection. The study of $T$. gondii has made significant contributions to the field of immunology and is well-suited to continue to do so, in understanding cytokine function and investigating human immune responses. Hopefully, in the next 100 years of $T$. gondii research, investigators will be able to better understand how the innate and adaptive immune systems are coordinated and controlled in mice and humans, develop a protective vaccine to prevent congenital toxoplasmosis and generate new effective treatment regimens for patients affected by toxoplasmosis. The greatest challenge will be to intelligently question our current models for understanding the immune response to $T$. gondii and creatively test these models to move the field forward.

\section{REFERENCES}

Abou-Bacar A, Pfaff AW, Georges S, Letscher-Bru V, Filisetti D, Villard O, Antoni E, Klein JP, Candolfi E 2004. Role of NK cells and $\gamma$ interferon in transplacental passage of Toxoplasma gondii in a mouse model of primary infection. Infect Immun 72: 1397-1401.

Ajioka JW, Soldati D 2007. Preface. In JW Ajoika, D Soldati (eds.), Toxoplasma Molecular and Cellular Biology, Horizon Bioscience, Norfolk, p. 13-18.

Alfonzo M, Blanc D, Troadec C, Huerre M, Eliaszewicz M, Gónzalez G, Koyanagi Y, Scott-Algara D 2002. Temporary restoration of immune response against Toxoplasma gondii in HIV-infected individuals after HAART, as studied in the hu-PBMC-SCID mouse model. Clin Exp Immunol 129: 411-419.

Aliberti J 2005. Host persistence: exploitation of anti-inflammatory pathways by Toxoplasma gondii. Nat Rev Immunol 5: 162-170.

Aliberti J, Reis e Sousa C, Schito M, Hieny S, Wells T, Huffnagle GB, Sher A 2000. CCR5 provides a signal for microbial induced production of IL-12 for CD8 $\alpha^{+}$dendritic cells. Nat Immunol 1: 83-87.

Armstrong D, Young LS, Meyer RD, Blevins AH 1971. Infectious complications of neoplastic disease. Med Clin North Am 55: 729-745.

Artis DA, Villarino A, Silverman M, He W, Thornton EM, Mu S, Summer S, Covey TM, Huang E, Yoshida H, Koretzky G, Goldschmidt M, Wu GD, de Sauvage F, Miller HR, Saris CJ, Scott P, Hunter CA 2004. The IL-27 receptor (WSX-1) is an inhibitor of innate and adaptive elements of Type 2 immunity. J Immunol 173: 5626-5634.

Aversa G, Punnonen J, Carballido JM, Cocks BG, de Vries JE 1994. CD40 ligand-CD40 interaction in Ig isotype switching in mature and immature human B cells. Semin Immunol 6: 295-301. 
Awasthi A, Carrier Y, Peron JP, Bettelli E, Kamanaka M, Flavell RA, Kuchroo VK, Oukka M, Weiner HL 2007. A dominant function for interleukin 27 in generating interleukin 10-producing antiinflammatory T cells. Nat Immunol 8: 1380-1389.

Batten M, Li J, Yi S, Kljavin NM, Danilenko DM, Lucas S, Lee J, de Sauvage FJ, Ghilardi N 2006. Interleukin 27 limits autoimmune encephalomyelitis by suppressing the development of interleukin 17-producing T cells. Nat Immunol 7: 929-936.

Blanchard N, Gonzalez F, Schaeffer M, Joncker NT, Cheng T, Shastri AJ, Robey EA, Shastri N 2008. Immunodominant, protective response to the parasite Toxoplasma gondii requires antigen processing in the endoplasmic reticulum. Nat Immunol 9: 937-944.

Bliss SK, Marshall AJ, Zhang Y, Denkers EY 1999. Human polymorphonuclear leukocytes produce IL-12, TNF- $\alpha$, and the chemokines macrophage-inflammatory protein-1 $\alpha$ and $-1 \beta$ in response to Toxoplasma gondii antigens. J Immunol 162: 7369-7375.

Boes M, Cerny J, Massol R, Op den Brouw M, Kirchhausen T, Chen J, Ploegh HL 2002. T-cell engagement of dendritic cells rapidly rearranges MHC class II transport. Nature 418: 983-988.

Burke JM, Roberts CW, Hunter CA, Murray M, Alexander J 1994. Temporal differences in the expression of mRNA for IL-10 and IFN- $\gamma$ in the brains and spleens of C57BL/10 mice infected with Toxoplasma gondii. Parasite Immunol 16: 305-314.

Candolfi E, Hunter CA, Remington JS 1995. Roles of $\gamma$ interferon and other cytokines in suppression of the spleen cell proliferative response to concavalin A and Toxoplasma antigens during actue toxoplasmosis. Infect Immun 63: 751-756.

Chan SH, Perussia B, Gupta JW, Kobayashi M, Pospísil M, Young HA, Wolf SF, Young D, Clark SC, Trinchieri G 1991. Induction of interferon $\gamma$ production by natural killer cell stimulatory factor: characterization of the responder cells and synergy with other inducers. $J$ Exp Med 173: 869-879.

Chtanova T, Schaeffer M, Han SJ, van Dooren GG, Nollmann M, Herzmark P, Chan SW, Satija H, Camfield K, Aaron H, Striepen B, Robey EA 2008. Dynamics of neutrophil migration in lymph nodes during infection. Immunity 29: 487-496.

Collazo CM, Yap GS, Sempowski GD, Lusby KC, Tessarollo L, Woude GF, Sher A, Taylor GA 2001. Inactivation of LRG-47 and IRG-47 reveals a family of interferon $\gamma$-inducible genes with essential, pathogen-specific roles in resistance to infection. $J \operatorname{Exp}$ Med 194: 181-188.

Collison LW, Workman CJ, Kuo TT, Boyd K, Wang Y, Vignali KM, Cross R, Sehy D, Blumberg RS, Vignali DA 2007. The inhibitory cytokine IL-35 contributes to regulatory T-cell function. Nature 450: 566-569.

Couper KN, Blount DG, Riley EM 2008. IL-10: the master regulator of immunity to infection. J Immunol 180: 5771-5777.

Courret N, Darche S, Sonigo P, Milon G, Buzoni-Gâtel D, Tardieux I 2006. CD11c- and CD11b-expressing mouse leukocytes transport single Toxoplasma gondii tachyzoites to the brain. Blood 107: 309-316.

Dellacasa-Lindberg I, Hitziger N, Barragan A 2007. Localized recrudescence of Toxoplasma infections in the central nervous sysem of immunocompromised mice assessed by in vivo bioluminescent imaging. Microbes Infect 9: 1291-1298.

Derouin F, Devergie A, Auber P, Gluckman E, Beauvais B, Garin YJ, Lariviere M 1992. Toxoplasmosis in bone marrow-transplant recipients: report of seven cases and review. Clin Infect Dis 15: 267-270.

Desmonts G, Couvreur J 1984. Congenital toxoplasmosis. Prospective study of the outcome of pregnancy in 542 women with toxoplasmosis acquired during pregnancy. Ann Pediatr (Paris) 31: 805-809.
Dunn D, Wallon M, Peyron F, Petersen E, Peckham C, Gilbert R 1999. Mother-to-child transmission of toxoplasmosis: risk estimates for clinical counseling. Lancet 353: 1829-1833.

Dzierszinski FS, Hunter CA 2008. Advances in the use of genetically engineered parasites to study immunity to Toxoplasma gondii. Parasite Immunol 30: 235-244.

Dzierszinski F, Pepper M, Stumhofer JS, LaRosa DF, Wilson EH, Turka LA, Halonen SK, Hunter CA, Roos DS 2007. Presentation of Toxoplasma gondii antigens via the endogenous major histocompatibility complex class I pathways in nonprofessional and professional antigen-presenting cells. Infect Immun 75: 5200-5209.

Fiorentino DF, Bond MW, Mosmann TR 1989. Two types of mouse T helper cell. IV. Th2 clones secrete a factor that inhibits cytokine production by Th1 clones. J Exp Med 170: 2081-2095.

Fischer A 2007. Human primary immunodeficiency diseases. Immunity 27: 835-845.

Fitzgerald DC, Zhang GX, El-Behi M, Fonseca-Kelly Z, Li H, Yu S, Saris CJ, Gran B, Ciric B, Rostami A 2007. Suppression of autoimmune inflammation of the central nervous system by interleukin 10 secreted by interleukin 27 -stimulated T cells. Nat Immunol 8: 1372-1379.

Frenkel JK 1967. Adoptive immunity to intracellular infection. $J$ Immunol 98: 1309-1319.

Frenkel JK, Amare M, Larsen W 1978. Immune competence in a patient with Hodgkin's disease and relapsing toxoplasmosis. Infection 6: 84-91.

Freshman MM, Merigan TC, Remington JS, Brownlee IE 1966. In vitro and in vivo antiviral action of an interferon-like substances induced by Toxoplasma gondii. Proc Soc Exp Biol Med 123: 862-866.

Frickel E-M, Sahoo N, Hopp J, Gubbels MJ, Craver MP, Knoll LJ, Ploegh HL, Grotenburg JL 2008. Parasite stage-specific recognition of endogenous Toxoplasma gondii-derived $\mathrm{CD} 8^{+} \mathrm{T}$ cell epitopes. J Infect Dis 198: 1625-1633.

Fuentes I, Rubio JM, Ramírez C, Alvar J 2001. Genotypic characterization of Toxoplasma gondii strains associated with human toxoplasmosis in Spain: direct analysis from clinical samples. $J$ Clin Microbiol 39: 1566-1570.

Garside P, Brewer JM 2008. Real-time imaging of the cellular interactions underlying tolerance, priming and responses to infection. Immunol Rev 221: 130-146.

Gavrilescu LC, Butcher BA, Del Rio L, Taylor GA, Denkers EY 2004. STAT1 is essential for antimicrobial effector function but dispensable for $\gamma$ interferon production during Toxoplasma gondii infection. Infect Immun 72: 1257-1264.

Gazzinelli RT, Hakim FT, Hieny S, Shearer GM, Sher A 1991. Synergistic role of $\mathrm{CD}^{+}$and $\mathrm{CD} 8^{+} \mathrm{T}$ lymphocytes in IFN- $\gamma$ production and protective immunity induced by an attenuated Toxoplasma gondii vaccine. J Immunol 146: 86-292.

Gazzinelli RT, Hayashi S, Wysocka M, Carrera L, Kuhn R, Muller W, Roberge F, Trinchieri G, Sher A 1994a. Role of IL-12 in the initiation of cell mediated immunity by Toxoplasma gondii and its regulation by IL-10 and nitric oxide. J Eukaryot Microbiol 41: 9S.

Gazzinelli RT, Heiny S, Wynn TA, Wolf S, Sher A 1993. Interleukin 12 is required for the T-lymphocyte-independent induction of interferon $\gamma$ by an intracellular parasite and induces resistance in T-cell-deficient hosts. Proc Natl Acad Sci USA 90: 6115-6119.

Gazzinelli RT, Oswald IP, James SL, Sher A 1992a. IL-10 inhibits parasite killing and nitrogen oxide production by IFN- $\gamma$-activated macrophages. J Immunol 148: 1792-1796. 
Gazzinelli RT, Wysocka M, Hayashi S, Denkers EY, Hieny S, Caspar P, Trinchieri G, Sher A 1994b. Parasite-induced IL-12 stimulates early IFN- $\gamma$ synthesis and resistance during acute infection with Toxoplasma gondii. J Immunol 153: 2533-2543.

Gazzinelli RT, Wysocka M, Hieny S, Scharton-Kersten T, Cheever A, Kühn R, Müller W, Trinchieri G, Sher A 1996. In the absence of endogenous IL-10, mice acutely infected with Toxoplasma gondii succumb to a lethal immune response dependent on $\mathrm{CD} 4^{+} \mathrm{T}$ cells and accompanied by overproduction of IL-12, IFN- $\gamma$ and TNF- $\alpha$. J Immunol 157: 798-805.

Gazzinelli RT, Xu Y, Hieny S, Cheever A, Sher A 1992b. Simultaneous depletion of $\mathrm{CD}^{+}$and $\mathrm{CD} 8^{+} \mathrm{T}$ lymphocytes is required to reactivate chronic infection with Toxoplasma gondii. J Immunol 149: $175-180$

Germain RN, Castellino F, Chieppa M, Egen JG, Huang AY, Koo LY, Qi H 2005. An extended vision for dynamic high-resolution intravital immune imaging. Semin Immunol 17: 431-441.

Germain RN, Miller MJ, Dustin ML, Nussenzweig MC 2006. Dynamic imaging of the immune system: progress, pitfalls and promise. Nat Rev Immunol 6: 497-507.

Gubbels MJ, Striepen B, Shastri N, Turkoz M, Robey EA 2005. Class I major histocompatibility complex presentation of antigens that escape from the parasitophorous vacuole of Toxoplasma gondii. Infect Immun 73: 703-711.

Hakes TB, Armstrong D 1983. Toxoplasmosis. Problems in diagnosis and treatment. Cancer 52: 1535-1540.

Hara T, Ohashi S, Yamashita Y, Abe T, Hisaeda H, Himeno K, Good $\mathrm{RA}$, Takeshita K 1996. Human $\mathrm{V} \delta 2^{+} \gamma \delta \mathrm{T}$-cell tolerance to foreign antigens of Toxoplasma gondii. Proc Natl Acad Sci USA 93: 5136-5140

Hemmer B, Frohman E, Hartung HP, Stüve O 2006. Central nervous system infections - a potential complication of systemic immunotherapy. Curr Opin Neurol 19: 271-276.

Hibbert L, Pflanz S, De Waal Malefyt R, Kastelein RA 2003. IL-27 and IFN- $\alpha$ signal via Stat1 and Stat 3 and induce T-bet and IL12Rß2 in naïve T cells. J Interferon Cytokine Res 23: 513-522.

Hitziger N, Dellacasa I, Albiger B, Barragan A 2005. Dissemination of Toxoplasma gondii to immunopriveleged organs and role of Toll/interleukin-1 receptor signaling for host resistance assessed by in vivo bioluminescence imaging. Cell Microbiol 7: 837-848.

Horowitz SL, Bentson JR, Benson F, Davos I, Pressman B, Gottlieb MS 1983. CNS toxoplasmosis in acquired immunodeficiency syndrome. Arch Neurol 40: 649-652.

Hunter CA, Abrams JS, Beaman MH, Remington JS 1993. Cytokine mRNA in the central nervous system of SCID mice infected with Toxoplasma gondii: importance of T-cell-independent regulation of resistance to T. gondii. Infect Immun 61: 4038-4044.

Hunter CA, Candolfi E, Subauste C, Van Cleave V, Remington JS 1995. Studies on the role of interleukin-12 in acute murine toxoplasmosis. Immunology 84: 16-20.

Hunter CA, Subauste CS, Van Cleave VH, Remington JS 1994. Production of $\gamma$ interferon by natural killer cells from Toxoplasma gondiiinfected SCID mice: regulation by interleukin-10, interleukin-12, and tumor necrosis factor $\alpha$. Infect Immun 62: 2818-2824.

Israelski DM and Remington JS 1993. Toxoplasmosis in patients with cancer. Clin Infect Dis Suppl 2: S423-435.

Jankovic D, Kullberg MC, Feng CG, Goldszmid RS, Collazo CM, Wilson M, Wynn TA, Kamanaka M, Flavell RA, Sher A 2007. Conventional T-bet ${ }^{+}$Foxp3- Th1 cells are the major source of hostprotective regulatory IL-10 during intracellular protozoan infection. $J$ Exp Med 204: 273-283.
Jones JL, Hanson DL, Chu SY, Ciesielski CA, Kaplan JE, Ward JW, Navin TR 1996. Toxoplasmic encephalitis in HIV-infected persons: risk factors and trends. The Adult/Adolescent Spectrum of Disease Group. AIDS 10: 1393-1399.

Kelly CD, Russo CM, Rubin BY, Murray HW 1989. Antigen-stimulated human interferon- $\gamma$ generation: role of accessory cells and their expressed or secreted products. Clin Exp Immunol 77: 397-402.

Khan IA, Matsuura T, Kasper LH 1994. Interleukin-12 enhances murine survival against acute toxoplasmosis. Infect Immun 62: $1639-1642$

Khan IA, Matsuura T, Kasper LH 1995. IL-10 mediates immunosuppression following primary infection with Toxoplasma gondii in mice. Parasite Immunol 17: 185-195.

Kobayashi M, Fitz L, Ryan M, Hewick RM, Clark SC, Chan S, Loudon R, Sherman F, Perussia B, Trinchieri G 1989. Identification and purification of natural killer cell stimulatory factor (NKSF), a cytokine with multiple biologic effects on human lymphocytes. J Exp Med 170: 827-845.

Kwok LY, Lütjen S, Soltek S, Soldati D, Busch D, Deckert M, Schlüter D 2003. The induction and kinetics of antigen-specific CD8 T cells are defined by the stage specificity and compartmentalization of the antigen in murine toxoplasmosis. J Immunol 170: 1949-1957.

Lambert H, Hitziger N, Dellacasa I, Svensson M, Barragan A 2006. Induction of dendritic cell migration upon Toxoplasma gondii infection potentiates parasite dissemination. Cell Microbiol 8: 1611-1623.

Lappalainen M, Jokiranta TS, Halme L, Tynninen O, Lautenschlager I, Hedman K, Höckerstedt K, Meri S 1998. Disseminated toxoplasmosis after liver transplantation: case report and review. Clin Infect Dis 27: 1327-1328.

Letscher-Bru V, Pfaff AW, Abou-Bacar A, Filisetti D, Antoni E, Villard O, Klein JP, Candolfi E 2003. Vaccination with Toxoplasma gondii SAG-1 protein is protective against congenital toxoplasmosis in BALB/c mice but not in CBA/J mice. Infect Immun 71: 6615-6619.

Levy RM, Janssen RS, Bush TJ, Rosenblum ML 1988. Neuroepidemiology of acquired immunodeficiency syndrome. $J$ Acquir Immun Defic Syndr 1: 31-40.

Lieberman LA, Banica M, Reiner SL, Hunter CA 2004. STAT1 plays a critical role in the regulation of antimicrobial effector mechanisms, but not in the development of Th1-type responses during toxoplasmosis. J Immunol 172: 457-463.

Lieberman LA, Hunter CA 2002. The role of cytokines and their signaling pathways in the regulation of immunity to Toxoplasma gondii. Int Rev Immunol 21: 373-403.

Liu CH, Fan YT, Dias A, Esper L, Corn RA, Bafica A, Machado FS, Aliberti J 2006. Cutting edge: dendritic cells are essential for in vivo IL-12 production and development of resistance against Toxoplasma gondii infection in mice. J Immunol 177: 31-35.

Lucas S, Ghilardi N, Li J, de Sauvage FJ 2003. IL-27 regulates IL-12 responsiveness of naïve $\mathrm{CD}^{+} \mathrm{T}$ cells through Stat1-dependent and -independent mechanisms. Proc Natl Acad Sci USA 100: $15047-15052$

Luft BJ, Brooks RG, Conley FK, McCabe RE, Remington JS 1984. Toxoplasmic encephalitis in patients with acquired immune deficiency syndrome. JAMA 252: 913-917.

Mallone R, Nepom GT 2004. MHC Class II tetramers and the pursuit of antigen-specific T cells: define, deviate, delete. Clin Immunol 110: $232-242$.

Martens S, Parvanova I, Zerrahn J, Griffiths G, Schell G, Reichmann 
G, Howard JC 2005. Disruption of Toxoplasma gondii parasitophorous vacuoles by the mouse p47-resistance GTPases. PLoS Pathog 1: e24.

McCabe RE 2001. Antitoxoplasma chemotherapy. In HM Joynson, TG Wreghitt (eds.), Toxoplasmosis, Cambridge University Press, Cambridge, p. 319-359.

McKee AS, Dzierszinski F, Boes M, Roos DS, Pearce EJ 2004. Functional inactivation of immature dendritic cells by the intracellular parasite Toxoplasma gondii. J Immunol 173: 2632-2640.

McLeod R, Beem MO, Estes RG 1985. Lymphocyte anergy specific to Toxoplasma gondii antigens in a baby with congenital toxoplasmosis. J Clin Lab Immunol 17: 149-153.

Mempel TR, Scimone ML, Mora JR, von Andrian UH 2004. In vivo imaging of leukocyte trafficking in blood vessels and tissues. Curr Opin Immunol 16: 406-417.

Mévélec MN, Bout D, Desolme B, Marchand H, Magné R, Bruneel O, Buzoni-Gatel D 2005. Evaluation of protective effect of DNA vaccination with genes encoding antigens GRA4 and SAG1 associated with GM-CSF plasmid, against acute, chronical and congenital toxoplasmosis in mice. Vaccine 23: 4489-4499.

Miyazaki Y, Inoue H, Matsumura M, Matsumoto K, Nakano T, Tsuda M, Hamano S, Yoshimura A, Yoshida H 2005. Exacerbation of experimental allergic asthma by augmented $\mathrm{Th} 2$ responses in WSX-1-deficient mice. J Immunol 175: 2401-2407.

Mohrs M, Shinkai K, Mohrs K, Locksley RM 2001. Analysis of type 2 immunity in vivo with a bicistronic IL-4 reporter. Immunity 15: 303-311.

Moore KW, de Waal Malefyt MR, Coffman RL, O’Garra A 2001. Interleukin-10 and theinterleukin-10 receptor. Annu Rev Immunol 19: 683-765.

Mun HS, Aosai F, Norose K, Chen M, Piao LX, Takeuchi O, Akira $\mathrm{S}$, Ishikura H, Yano A 2003. TLR2 as an essential molecule for protective immunity against Toxoplasma gondii infection. Int Immunol 15: 1081-1087.

Nathan CF, Murray HW, Wiebe ME, Rubin BY 1983. Identification of interferon- $\gamma$ as the lymphokine that activates human macrophage oxidative metabolism and antimicrobial activity. $J$ Exp Med 158: 670-689.

Neyer LE, Grunig G, Fort M, Remington JS, Rennick D, Hunter CA 1997. Role of interleukin-10 in regulation of T-cell-dependent and T-cell-independent mechanisms of resistance to Toxoplasma gondii. Infect Immun 65: 1675-1682.

Nicolle C 1907. Sur une piroplasmose nouvelle d'un rongeur. C R Soc Biol 63: 380- 399.

Nicolle C, Manceaux L 1908. Sur une infection á corps de Leishman (ou organisms voisons) du gondi. CR Acad Sci 147: 763-766.

Nicolle C, Manceaux L 1909. Sur une protozoaire nouveau du gondi. CR Acad Sci 148: 369-372.

O'Garra A, Vieira P 2007. T(H)1 cells control themselves by producing interleukin-10. Nat Rev Immunol 7: 425-428.

Parker SJ, Roberts CW, Alexander J 1991. CD8 ${ }^{+}$T cells are the major lymphocyte subpopulation involved in the protective immune response to Toxoplasma gondii in mice. Clin Exp Immunol 84: 207-212.

Pepper M, Dzierszinski F, Crawford A, Hunter CA, Roos D 2004. Development of a system to study CD4+-T-cell responses to transgenic ovalbumin-expressing Toxoplasma gondii during toxoplasmosis. Infect Immun 72: 7240-7246.

Pepper M, Dzierszinski F, Wilson E, Tait E, Fang Q, Yarovinsky F,
Laufer TM, Roos D, Hunter CA 2008. Plasmacytoid dendritic cells are activated by Toxoplasma gondii to present antigen and produce cytokines. J Immunol 180: 6229-6236.

Persson EK, Agnarson AM, Lambert H, Hitziger N, Yagita H, Chambers BJ, Barragan A, Grandien A 2007. Death receptor ligation or exposure to perforin trigger rapid egress of the intracellular parasite Toxoplasma gondii. J Immunol 179: 8357-65.

Petersen E, Dubey JP 2001. Biology of toxoplasmosis. In DHM Joynson, TG Wreghitt (eds.), Toxoplasmosis, Cambridge University Press, Cambridge, p. 1-42.

Pfaff AW, Abou-Bacar A, Letscher-Bru V, Villard O, Senegas A, Mousli M, Candolfi E 2007. Cellular and molecular physiopathology of congenital toxoplasmosis: the dual role of IFN- $\gamma$. Parasitology 134: 1895-1902.

Pflanz S, Hibbert L, Mattson J, Rosales R, Vaiberg E, Bazan JF, Phillips JH, McClanahan TK, de Waal Malefyt R, Kastelein RA 2004. WSX-1 and glycoprotein 130 constitute a signal-transducing receptor for IL-27. J Immunol 172: 2225-2231.

Pflanz S, Timans JC, Cheung J, Rosales R, Kanzler H, Gilbert J, Hibbert L, Churakova T, Travis M, Vaisberg E, Blumenschein WM, Mattson JD, Wagner JL, To W, Zurawski S, McClanahan TK, Gorman DM, Bazan JF, de Waal Malefyt R, Rennick D, Kastelein RA 2002. IL-27, a heterodimeric cytokine composed of EBI3 and p28 protein, induces proliferation of naïve $\mathrm{CD}^{+} \mathrm{T}$ cells. Immunity 16: 779-790.

Pitchenik AE, Fischl MA, Dickinson GM, Becker DM, Fournier AM, O'Connell MT, Colton RM, Spira TJ 1983. Opportunistic infections and Kaposi's sarcoma among Haitians: evidence of a new acquired immunodeficiency state. Ann Intern Med 98: 277-284.

Reinhardt RL, Hong S, Kang SJ, Wang ZE, Locksley RM 2006. Visualization of IL-12/23p40 in vivo reveals immunostimulatory dendritic cell migrants that promote Th1 differentiation. $J$ Immunol 177: 1618-1627.

Reis e Sousa C, Hieny S, Scharton-Kersten T, Jankovic D, Charest H, Germain RN, Sher 1997. In vivo microbial stimulation induces rapid CD40 ligand-independent production of interleukin 12 by dendritic cells and their redistribution to T cell areas. J Exp Med 186: 1819-1829.

Remington JS 1974. Toxoplasmosis in the adult. Bull NY Acad Med 50: $211-227$.

Remington JS, Krahenbuhl JL, Mendenhall JW 1972. A role for activated macrophages in resistance to infection with Toxoplasma. Infect Immun 6: 829-834.

Remington JS, McLeod R, Thulliez P, Desmonts G 2000. Toxoplasmosis. In JS Remington, JO Klein (eds.), Diseases of the fetus and newborn infant, $\mathrm{W}$ H Saunders Company, Philadelphia, $\mathrm{p}$. 205-346.

Remington JS, Merigan TC 1968. Interferon: protection of cells infected with an intracellular protozoan (Toxoplasma gondii). Science 161: 804-806.

Rosas LE, Satoskar AA, Roth KM, Keiser TL, Barbi J, Hunter C, de Sauvage FJ, Satoskar AR 2006. Interleukin-27R (WSX-1/T-cell cytokine receptor) gene-deficient mice display enhanced resistance to Leishmania donovani infection but develop severe liver immunopathology. Am J Pathol 168: 158-169.

Ruskin J, Remington JS 1976. Toxoplasmosis in the compromised host. Ann InternMed 84: 193-199.

Rytel MW, Jones TC 1968. Induction of interferon in mice infected with Toxoplasma gondii. Proc Soc Exp Biol Med 123: 859-862.

Sabin AB, Feldman HA 1948. Dyes as microchemical indicators of a 
new immunity phenomenon affecting a protozoan parasite (Toxoplasma). Science 108: 660-663.

Saeij JP, Arrizabalaga G, Boothroyd JC 2008. A cluster of four surface antigen genes specifically expressed in bradyzoites, SAG2CDXY, plays an important role in Toxoplasma gondii persistence. Infect Immun 76: 2402-2410.

Saeij JP, Boyle JP, Grigg ME, Arrizabalaga G, Boothroyd JC 2005. Bioluminescence imaging of Toxoplasma gondii infection in living mice reveal dramatic differences between strains. Infect Immun 73: 695-702.

Scharton-Kersten TM, Yap G, Magram J, Sher A 1997. Inducible nitric oxide is essential for host control of persistent but not acute infection with the intracellular pathogen Toxoplasma gondii. $J$ Exp Med 185: 1261-1273.

Serbina N, Pamer EG 2003. Quantitative studies of CD8 $8^{+} \mathrm{T}$ cell responses during microbial infection. Curr Opin Immunol 15: 436-442.

Shimizu S, Sugiyama N, Masutani K, Sadanaga A, Miyazaki Y, Inoue Y, Akahoshi M, Katafuchi R, Hirakata H, Harada M, Hamano S, Nakashima H, Yoshida H 2005. Membranous glomerulonephritis development with Th2-type immune deviations in MRL/lpr mice deficient for IL-27 receptor (WSX-1). J Immunol 175: 7185-7192.

Sonoda KH, Yoshimura T, Takeda A, Ishibashi T, Hamano S, Yoshida H 2007. WSX-1 plays a significant role for the initiation of experimental autoimmune uveitis. Int Immunol 19: 93-98.

Splendore A 1908. Un nuovo protozoa parassita de'conigli. Incontrato nelle lesioni anatomiche d'une malattia che ricorda in molti punti il Kala-azar dell'uomo. Nota preliminaire pel. Rev Soc Sci Sao Paulo 5: 167

Stetson DB, Mohrs M, Reinhardt RL, Baron JL, Wang ZE, Gapin L, Kronenberg M, Locksley RM 2003. Constitutive cytokine mRNAs mark natural killer (NK) and NK T cells poised for rapid effector function. J Exp Med 198: 1069-1076.

Striepen B, He CY, Matrajt M, Soldati D, Roos DS 1998. Expression, selection and organellar targeting of the green fluorescent protein in Toxoplasma gondii. Mol Biochem Parasitol 92: 325-338.

Stumhofer JS, Laurence A, Wilson EH, Huang E, Tato CM, Johnson LM, Villarino AV, Huang Q, Yoshimura A, Sehy D, Saris CJ, O'Shea JJ, Hennighausen L, Ernst M, Hunter CA 2006. Interleukin 27 negatively regulates the development of interleukin 17 -producing $\mathrm{T}$ helper cells during chronic inflammation of the central nervous system. Nat Immunol 7: 937-945

Stumhofer JS, Silver JS, Laurence A, Porret PM, Harris TH, Turka LA, Ernst M, Saris CJ, O'Shea JJ, Hunter CA 2007. Interleukins 27 and 6 induce STAT3-mediated T cell production of interleukin 10. Nat Immunol 8: 1363-1371.

Subauste CS, Wessendarp M, Sorensen RU, Leiva LE 1999. CD40CD40 ligand interaction is central to cell-mediated immunity against Toxoplasma gondii: patients with hyper IgM syndrome have a defective type 1 immune response that can be restored by soluble CD40 ligand trimer. J Immunol 162: 6690-6700.

Sumen C, Mempel TR, Mazo IB, von Andrian UH 2004. Intravital microscopy: visualizing immunity in context. Immunity 21: 315-329.

Suzuki Y, Conley FK, Remington JS 1989. Importance of endogenous IFN- $\gamma$ for prevention of toxoplasmic encephalitis in mice. $J$ Immunol 143: 2045-2050.

Suzuki Y, Kobayashi A 1990. Induction of tolerance to Toxoplasma gondii in newborn mice by maternal antibody. Parasitol Res 76: 424-427.
Suzuki Y, Orellana MA, Schreiber RD, Remington JS 1988. Interferon- $\gamma$ : the major mediator of resistance against Toxoplasma gondii. Science 240: 516-518.

Suzuki Y, Remington JS 1988. Dual regulation of resistance against Toxoplasma gondii infection by Lyt- $2^{+}$and $\mathrm{Lyt}^{-} \mathrm{1}^{+}, \mathrm{L} 3 \mathrm{~T} 4^{+} \mathrm{T}$ cells in mice. J Immunol 140: 3943-3946.

Suzuki Y, Sher A, Yap G, Park D, Neyer LE, Liesenfeld O, Fort M, Kang H, Gufwoli E 2000. IL-10 is required for prevention of necrosis in the small intestine and mortality in both genetically resistant $\mathrm{BALB} / \mathrm{c}$ and susceptible $\mathrm{C} 57 \mathrm{BL} / 6$ mice following peroral infection with Toxoplasma gondii. J Immunol 164: 5375-5382.

Takeda K, Hamano S, Yamanaka A, Hanada T, Ishibashi T, Mak TW, Yoshimura A, Yoshida H 2003. Cutting edge: role of IL-27/WSX1 signnaling for induction of T-bet through activation of STAT1 during initial Th1 commitment. J Immunol 170: 4886-4890.

Taylor GA, Collazo CM, Yap GS, Nguyen K, Gregorio TA, Taylor LS, Eagleson B, Secrest L, Southon EA, Reid SW, Tessarollo L, Bray M, McVicar DW, Komschlies KL, Young HA, Biron CA, Sher A, Vande Woude GF 2000. Pathogen-specific loss of host resistance in mice lacking the IFN- $\gamma$-inducible gene IGTP. Proc Natl Acad Sci USA 97: 751-755.

Villarino A, Hibbert L, Lieberman L, Wilson E, Mak T, Yoshida H, Kastelein RA, Saris C, Hunter CA 2003. IL-27R (WSX-1) is required to suppress $\mathrm{T}$ cell hyperactivity during infection. Immunity 19: 645-655.

Villegas EN, Wille U, Craig L, Linsley PS, Rennick DM, Peach R, Hunter CA 2000. Blockade of costimulation prevents infectioninduced immunopathology in interleukin-10-deficient mice. Infect Immun 68: 2837-2844.

Vollmer TL, Waldor MK, Steinman L, Conley FK 1987. Depletion of T-4 lymphocytes with monoclonal antibody reactivates toxoplasmosis in the central nervous system: a model of superinfection in AIDS. J Immunol 138: 3737-3741.

Wensing AM, Boucher CA 2003. Worldwide transmission of drugresistant HIV. AIDS Rev 5: 140-155.

Wille U, Villegas EN, Craig L, Peach R, Hunter CA 2002. Contribution of interleukin-12 (IL-12) and the CD28/B7 and CD40/CD40 ligand pathways to the development of a pathological T-cell response in IL-10-deficient mice. Infect Immun 70: 6940-6947.

Wilson EH, Wille-Reece U, Dzierszinski F, Hunter CA 2005. A critical role for IL-10 in limiting inflammation during toxoplasmic encephalitis. J Neuroimmunol 165: 63-74.

Wirtz S, Tubbe I, Galle PR, Schild HJ, Birkenbach M, Blumberg RS, Neurath MF 2006. Protection from lethal septic peritonitis by neutralizing the biological function of interleukin 27. J Exp Med 203: 1875-1881.

Wolf A, Cowen D, Paige B 1939. Human toxoplasmosis: occurrence in infants as an encephalomyelitis. Verification by transmission to animals. Science 89: 226-227.

Wong SY, Remington JS 1994. Toxoplasmosis in pregnancy. Clin Infect Dis 18: 853-861.

Yamamoto JH, Vallochi AL, Silveira C, Filho JK, Nussenblatt RB, Cunha-Neto E, Gazzinelli RT, Belfort R Jr, Rizzo LV 2000. Discrimination between patients with acquired toxoplasmosis and congenital toxoplasmosis on the basis of the immune response to parasite antigens. J Infect Dis 181: 2018-2022.

Yarovinsky F, Zhang D, Andersen JF, Bannenberg GL, Serhan CN, Hayden MS, Hieny S, Sutterwala FS, Flavell RA, Ghosh S, Sher A 2005. TLR11 activation of dendritic cells by a protozoan profilin-like protein. Science 308: 1626-1629. 